\title{
Performance of Concrete at Elevated Temperatures: Utilizing A Blended Ordinary Portland Cement (Opc)/ Saw Dust Ash (Sda) As Binder
}

\author{
Nimlyat, P. S. ${ }^{1}$ datok, E. P. ${ }^{2}$ \\ ${ }^{1}$ Department of Architecture, University of Jos \\ ${ }^{2}$ Department of Building University of Jos
}

\begin{abstract}
This study aimed at investigating the effect of subjecting concrete, produced with cement being partially replaced with saw dust ash (SDA) to elevated temperatures. The performance of the test concrete cubes was done by exposing them to elevated temperatures of $200 \mathrm{oC}, 400 \mathrm{oC}, 600 \mathrm{oC}$ and $800 \mathrm{oC}$, and allowed to cool down to room temperature before testing for their properties. Both the physical and thermal properties of the concrete cubes were determined. The concrete produced by blending cement with $10 \%$ SDA with an average percentage loss of $23.04 \%$ retained more of its compressive strength when exposed to the different temperatures, than concrete produced using only OPC, which has an average percentage loss of $29.11 \%$. It is also found that, at an elevated temperature of $800 \mathrm{oC}$, concrete fail totally in flexure due to the effect of high heat on binding elements. The flexural strength of both the control concrete (at $0 \%$ OPC replacement) and $O P C / S D A$ blended concrete (at 10\% OPC replacement) decreased as the temperature is increased. The replacement of OPC by 10\% SDA increased the thermal shock resistance of the concrete by 11 cycles than the $0 \%$ OPC concrete at the same temperature. The concrete produced with OPC has better thermal conductivity than the concrete produced by blending OPC with SDA, as a result, the dislodgement of the concrete edges is relatively lower in the SDA blended cement concrete than in the OPC concrete. The result shows that, blending $O P C$ with SDA in concrete performed better at elevated temperatures than concrete produced with only OPC. Therefore, the replacement of OPC with 10\% SDA can be applied as a fire resisting bonding material in concrete.
\end{abstract}

Keywords: Blended Concrete, Elevated Temperatures, Ordinary Portland cement (OPC), Performance, Saw Dust Ash (SDA)

\section{Introduction}

Concrete is a complex composite material and consist mainly of aggregates bonded together, by a softer matrix of hardened cement paste, surrounding the aggregates in a weak transition zone. Concrete contains about $40 \%$ capillarity pores of diameter between $1 \mathrm{~nm}$ to $1 \mathrm{~mm}$ and up to $28 \%$ gel pores, less than $2.6 \mathrm{~nm}$ in diameter [1]. Concrete when fresh, is a liquid paste that can be moulded into any desired shape and yet develops strength to carry different loadings, when matured. This unique characteristic advantage of concrete made it the most preferred choice for application in the construction industry. The cement component as a constituent of concrete is the main binder in translating the liquid paste into a rigid strong concrete. Studies have shown that pozzolanas can produce concrete that can be relatively compared with normal concrete in its characteristics [2] [3] [4]. Therefore, the replacement of ordinary Portland cement (OPC) by a percentage of pozzolanic material improves the strength and durability of concrete.

Concrete when exposed to high temperature (especially fire), deteriorate in its properties. Of particular importance are; loss in compressive strength, cracking and spalling of concrete [5], destruction of the bond between cement and the aggregates and the gradual deterioration of the hardened cement paste. Assessment of fire damaged on concrete usually starts with visual observation of colour change[6], cracking and spalling of the surface [5]. The ability of concrete to resist weathering actions, chemical attacks, abrasion, fire or any other process of deterioration makes it have good durability property. Concrete is termed durable, when it keeps to its form and shape within the allowable limits while exposed to different environmental conditions [5]. The hydration of cement produces calcium hydroxide $(\mathrm{Ca}(\mathrm{OH}) 2)$ which is associated with poor durability and poor fire resistivity. The chemical constituents of the pozzolana when mixed with cement react with the $(\mathrm{Ca}(\mathrm{OH}) 2)$ as the principal hydration product of cement to produced cementation. The process of this reaction removes $(\mathrm{Ca}(\mathrm{OH}) 2)$ from the mixture. The removal of this $(\mathrm{Ca}(\mathrm{OH}) 2)$ from the mixture has a significant influence on the resulting concrete resistance to high fire [7]. Concrete properties and concrete response to the influencing factors, such as loading, temperature and moisture depend on the properties of the concrete constituents. It can be said that the concrete microstructure derives its macro properties through the combined properties of different aggregate types and the cement paste (Cement Concrete and Aggregate Australia [8]. 
According to CCAA [8], the four main properties of concrete are workability, cohesiveness, strength and durability. The workability of concrete enables the material components to be compacted into forms having any reasonable shape while durability ensures a long life for the hardened mass of the concrete. During hydration and hardening, concrete develops certain physical and chemical properties. The mechanical strength and durability are considered to have an important role in the design process. Thermal properties of concrete are also an important aspect while dealing with durability of concrete. The study of thermal behaviour of concrete in different situations forms an important topic while dealing with durability of concrete. The most important aspects of thermal properties of concrete are;

a. Thermal conductivity of the concrete,

b. Coefficient of thermal expansion.

c. Fire resistance.

Concrete structures that may be subjected to a range of temperatures that are more severe than those imposed by the ambient environmental conditions includes; Building fires, Incinerators, Nuclear plants and Metallurgical buildings in proximity to furnace. The effect of elevated temperatures on certain mechanical and physical properties of concrete may determine whether the concrete will maintain its structural integrity or not. Study carried out by Morsy and Shebl [7] shows that, the replacement of Portland cement by $20 \%$ metakaoline in blended cement paste leads to increase in the thermal shock resistance up to 16 cycles. This is due to the pozzolanic activity of metakaoline during hydration. The addition of pozzolanas to OPC in concrete, therefore, has a way of improving the strength and durability of concrete, because of the interface reinforcement. Pozzolanas are discovered to have chemical constituents that react with those released by the chemical reaction during hydration of cement to form cementitious materials. When the chemical constituents of cement and pozzolanas react, calcium hydroxide $(\mathrm{Ca}(\mathrm{OH}) 2)$ is been removed from the mixture. The removal of this calcium hydroxide $(\mathrm{Ca}(\mathrm{OH}) 2)$ from the mixture improved the resistance of the concrete in aggressive environment. This chemical reaction increases the strength of the concrete thus formed and influence other concrete properties such as durability and thermal resistance.

Recent researches have shown that saw dust can be burnt into ash and used as a replacement of cement in concrete. The benefit of utilizing SDA pozzolana derived from agro-waste local resources is enormous. The conversion of saw dust into SDA Pozzolana, can create a significant benefit for the environment, by conserving material resources and avoiding landfill disposal of timber waste products. Therefore, the need to improve on the performance of concrete at elevated temperature blending cement with saw dust ash (SDA) pozzolana.

This study seeks to provide answers to certain research questions in the course of the investigation. The research questions to be addressed are;

1. What is the effect of elevated temperatures on the mechanical and thermal properties of SDA/OPC blended cement concrete?

2. Does SDA/OPC blended cement concrete perform better than OPC concrete when subjected to elevated temperatures?

This study is aimed at investigating the effect of subjecting concrete produced with cement partially replaced with saw dust ash (SDA) to elevated temperatures. The objectives of the research are;

1. To determine the compressive strength and flexural strength of preheated SDA pozzolana blended cement concrete at different thermal treatment of between $200 \mathrm{oC}$ to $800 \mathrm{oC}$.

2. To determine thermal conductivity and coefficient of thermal expansion of SDA/OPC blended cement concrete

3. To determine the thermal shock resistance and linear shrinkage of the blended cement concrete at a temperature of $800 \mathrm{oC}$.

\section{Concrete Behaviour at Elevated Temperature}

Concrete offers great fire resistance to structures [6] and is physically stable to about $550 \mathrm{oC}$, and, does not fail dramatically even at higher temperatures [9]. Concrete's thermal properties protect reinforcing steel and pre-stressing steel from structural failures acting as fireproofing coatings [6]. All of this does not mean that concrete is not adversely affected by fire or heat. In the event of fire, concrete structures are affected by various processes. This leads to degradation of the material and potentially spalling of the near-surface concrete layers [10]. When concrete is exposed to temperatures above $100 \mathrm{oC}$, evaporation begins to take place. Further rise in temperature will result into spalling of the concrete due to rising pressures that exceed the strength of the concrete [11]. Concrete, under normal atmospheric conditions, is typically exposed to temperatures below $50 \mathrm{oC}$. However, in fire conditions, concrete can be exposed to temperatures of up to $1200 \mathrm{oC}$ in less than 2 hours. When heat is conducted in concrete, many changes occur in it physical structure, chemical composition and fluid content. Therefore, the mechanical properties of concrete such as strength and stiffness, are significantly altered when exposed to high temperatures. Generally, it can be said that concrete has good properties with respect to fire resistance, when exposed to a temperature of up to $1000 \mathrm{oC}$ [12]. 
A review of methods used by various investigators for elevated-temperature testing of concrete indicates that, the tests can be categorized according to cold or hot testing [12]. In cold testing, specimens are gradually heated to a specified temperature, permitted to stabilize thermally at that temperature for a prescribed period, permitted to cool slowly to ambient, and then tested to determine residual mechanical properties. In hot testing, specimens are gradually heated to a specified temperature, and permitted to stabilize thermally at the temperature for a prescribed time, and then tested to determine mechanical properties. During testing, specimens are maintained in either an open environment where water vapour can escape (unsealed) or a closed environment where the moisture is contained (sealed). Mechanical properties in which the specimens have been permitted to return to room temperature prior to testing are referred to as residual properties.

\section{Temperature Effect on Pozzolanic Concrete}

Pozzolanic high strength concretes (HSC) is used extensively throughout the world. The application of such concretes is increasing day by day due to their superior structural performance, environmental friendliness, and energy conserving implication [13]. When fine pozzolana particles are dispersed in concrete paste, they generate a large number of nucleation sites for the precipitation of the hydration products [5]. Therefore, this process increase the consistency of the paste and becomes dense as for the distribution of the fine pores. Morsy, Shebl and Rashad [5], carried out an experimental investigation on the microstructure and compressive strength of pre-heated metakaoline - silica fume blended cement paste. The result shows that there is a considerable increase in compressive strength of the pre-heated blended cement than that of the control concrete. This increase in compressive strength of the blended cement concrete may be due to the pozzolanic reaction of metakaoline and silica fume with free lime to produced CSH and CAH. The increase can also be partially due to the strengthened hydrated cement pastes during the evaporation of free water, which result into forces that cause the cement gel layers to move closer to each other [14].

\section{Materials and Methods}

The Method employed for this research includes the review of relevant literatures and publications on concrete, and pozzolana admixture and the possible impact of fire to concrete. Other database information from texts and internet sources are used in establishing facts. The data collection also involved field works and laboratory experiments. The materials used for this study are cement, aggregates and SDA pozzolana. The production of the concrete for the test are prepared from ordinary Portland cement (OPC) that is partially substituted by SDA pozzolana using the standard water of consistence. The cement content in the concrete is substituted by $10 \%$ partial replacement with the SDA pozzolana. This proportion is based on an already conducted study, [3] [15] where an optimum replacement of cement with 10\% SDA pozzolana in concrete for workability and strength was suggested. The saw dust ash (SDA) used for this research resulted from waste products of Timber sawn in Timber sheds in Jos. The saw dust came mainly from species of timber such as Mansonia, Mahogany, Obeche and black Afara, which are common in the Nigerian market. The SDA is produced by burning saw dust at a temperature range of $500 \mathrm{oC}-600 \mathrm{oC}$ using a furnace at the National Metallurgical Development Centre (NMDC) Jos, Nigeria. The cooled ash is then grounded to very fine texture and sieved to a size less than $212 \mu \mathrm{m}$.

Laboratory tests carried out includes among others; Sieve analysis, Chemical analysis of cement and pozzolana. Also, thermal properties, compression and flexural strength test was carried out on the blended cement concrete subjected to certain different temperatures. The concrete cubes are cast in $150 \mathrm{~mm} \times 150 \mathrm{~mm} \times$ $150 \mathrm{~mm}$ mould and cure for 28 days, and the harden concrete is exposed to temperatures of $200 \mathrm{oC}, 400 \mathrm{oC}$, $500 \mathrm{oC}$ and $800 \mathrm{oc}$ for two hours to achieve thermal steady state. For flexural strength test, cylindrical beams were cast in a mould of size $500 \mathrm{~mm} \times 100 \mathrm{~mm} \times 100 \mathrm{~mm}$. Thermal shock resistance on the blended cement concretes is determined by heating the concrete (after 28 days hydration period) for about 40 minutes at $700 \mathrm{oC}$. This was followed by quenching in water for 5 minutes and the cycles repeated until the sample deteriorates.

\subsection{Density of unheated and heated concrete cubes}

\section{Results Presentation and Analysis}

The density of the test cubes is determined before and the heating. The values obtained for the unheated and heated concrete cubes are shown in Table 3. The result of the density indicates that, there is a relationship between the density and temperature change. The application of heat to the test cubes reduces its density relatively. Also, increasing the temperature at which the test cube is exposed to, the less the density of the concrete cube as shown in Table 3, Fig. 2 and Fig. 3.

Comparing the percentage loss in density of the $0 \%$ OPC replacement concrete and the $10 \%$ replacement SDA/OPC blended cement concrete after heating at the different temperature ranges, there is a significant difference. At a temperature of $400 \mathrm{oC}$, the percentage loss in density of $0 \%$ OPC replacement concrete cube is $4.51 \%$ while that for the $10 \%$ OPC replacement blended cement concrete is $3.36 \%$ at the same 
temperature. At the temperature of $800 \circ \mathrm{C}$, percentage decreased in density are $5.28 \%$ for the $0 \%$ OPC replacement concrete cubes and $5.04 \%$ for the $10 \% \mathrm{SDA} / \mathrm{OPC}$ blended cement concrete cubes. It can therefore, be said that, the SDA/OPC blended cement concrete is denser than the concrete made of $100 \%$ OPC and also, loss in density due to heat application is lower in the former than in the later. This is as a result of SDA having a lower specific gravity than that of cement.

\subsection{Compressive Strength}

Table 4 and Fig. 4 illustrate the typical development of compressive strength for the $0 \%$ and $10 \%$ OPC replacement in the control and blended cement concrete subjected to a temperature range of $200 \mathrm{oC}$ to $800 \mathrm{oC}$ for two hours. The compressive strength of concrete cubes made of $0 \%$ OPC replacement increased with temperature up to $400 \mathrm{oC}$ and then decreased up to $8000 \mathrm{C}$. The result also shows that, the $10 \% \mathrm{SDA} / \mathrm{OPC}$ blended cement concrete increased in compressive strength as the treatment temperature increased up to $600 \mathrm{oC}$, and decreased at the temperature of $800 \mathrm{oC}$. For the control concrete at $0 \%$ OPC replacement, the increased in strength up to $400 \mathrm{oC}$ may be the result of the hydration of unhydrated cement constituents due from the heat generated. For the 10\% OPC replacement in the blended cement concrete, the increased in compressive strength up to $600 \mathrm{oC}$ may be due to the pozzolanic reaction of the primary chemical constituents of the SDA pozzolana that are deposited within the pores of the concrete. The ability of the blended cement concrete to increase in strength even at $600 \mathrm{oC}$, is as a result of the reduction in $\mathrm{Ca}(\mathrm{OH}) 2$ content, by the action of $\mathrm{SiO} 2$ and $\mathrm{Al} 2 \mathrm{O} 3$ which are elements in the SDA. According to Morsy et al (2008), cement matrix with higher volumes of gel-like hydration products and lower crystalline $\mathrm{Ca}(\mathrm{OH}) 2$ contents has improved fire resistance. The decline in compressive strength of the $0 \%$ OPC replacement concrete is noticeable when the temperature is above $400 \mathrm{oC}$ while that of the $10 \%$ replacement in the blended cement concrete is noticeable at a temperature of above $600 \mathrm{oC}$.

Table 5 shows the result of the rate at which compressive strength is gain or loss with an increase in temperature. From the result, the average percentage strength gained of the control concrete (at $0 \%$ OPC replacement) is $10.22 \%$, which is higher, than the strength gain in the blended cement concrete $(10 \%$ OPC replacement) which is $7.59 \%$. Strength gain in the $10 \%$ OPC replacement, in the blended cement concrete, was slower but increased up to a temperature of $600 \mathrm{oC}$ due to the pozzolanic activity of the SDA. The hydration of cement consequently results into the liberation of lime. The liberated lime reacts with the pozzolana to increase the strength development of the SDA/OPC blended cement concrete. The average percentage loss in compressive strength of the $0 \%$ OPC replacement concrete at a temperature of over $400 \mathrm{oC}$ is $29.11 \%$. This is more than the average percentage loss in compressive strength of the SDA/OPC blended cement concrete at a temperature of over $600 \mathrm{oC}$. Since an increase in temperature resulted into decreased in densities, it is expected that compressive strength should decrease with an increase in temperature.

\subsection{Flexural Strength}

The development of indirect tensile strength of the test concrete cubes as measured by the flexural strength test is shown in Table 6 and Fig. 5. This test is carried out after subjecting the test cubes to different elevated temperatures of $200,400,600$, and $800 \mathrm{oC}$ after 28 days of curing. From the results, the flexural strength of the two different replacements under study reduces as the temperature increases from $200 \mathrm{oC}$ to $600 \mathrm{oC}$. There is no remarkable difference between the flexural strength of the concrete with $0 \%$ OPC replacement and the $10 \%$ replacement of the SDA/OPC blended cement concrete. At $800 \mathrm{oC}$, both the $0 \%$ OPC replacement concrete and the SDA/OPC blended cement concrete has no values for flexural strength. This is due to the effect of such a high heat on the binding elements of the concrete. Increasing the temperature of the test cubes resulted into decreased in their density as shown in Table 3. The flexural strength also decreases as the density also decreases. It is worthy of note that, the average loss in flexural strength of the SDA/OPC blended cement concrete at $10 \%$ replacement, is 0.05 lower than the loss in flexural strength of the $0 \%$ concrete as shown in Table 7. It can then be said that, SDA/OPC blended cement concrete can perform better in flexure under elevated temperature when compared to the $100 \%$ OPC concrete.

\subsection{Thermal Shock Resistance}

The performance of the concrete cubes is shown in Table 8 and Fig. 6 as a result of exposing the tests cubes to an elevated temperature of $800 \mathrm{o}$, the outer surface of the concrete which is in direct contact with the heat tends to expand more than the inner layers. When the heated concrete cube is cool by immersion in water, there is a differential deformation between the outer surface and the inner layers thereby resulting into cracks and deterioration of the concrete. The presence of the constituents of pozzolanic SDA increase the thermal shock resistance of the 10\% OPC replacement in the blended cement concrete, which is considerably higher than that of the control ( $0 \%$ OPC replacement). 


\subsection{Thermal Conductivity}

The variation of thermal conductivity of the $0 \%$ OPC concrete and $10 \% \mathrm{SAD} / \mathrm{OPC}$ blended cement concrete is presented in Table 9 and Fig. 7. The thermal conductivity of the $0 \%$ OPC replacement is 1.77 $\mathrm{W} / \mathrm{m} . \mathrm{K}$ while the thermal conductivity for the $10 \% \mathrm{SDA} / \mathrm{OPC}$ replacement is $1.68 \mathrm{~W} / \mathrm{m} . \mathrm{K}$. The result shows that the thermal conductivity of the blended cement concrete is a little lower than that for the control concrete. The saw dust ash (SDA) in the concrete reduced its conductivity thereby making it a lesser conductor of heat than the concrete made from $100 \%$ ordinary Portland cement (OPC). Saw dust ash (SDA) content, therefore, had only a slight influence on thermal conductivity of the concrete. This improves the durability of the concrete produced by blending OPC with SDA. Also from the result, the effect of temperature on the concrete produced of OPC is a little more than that of concrete produced by blending OPC with SDA as a result of the OPC conducting more heat than the SDA. The difference in their thermal conductivity also resulted into more cracking and spalling of the surfaces of the OPC concrete than the SDA blended concrete. It is pertinent to say that, concrete produced by replacing OPC with $10 \%$ SDA can be a better material for separating warm or hot parts from cold ones in concrete construction or furnaces.

\subsection{Linear Coefficient of Thermal Expansion}

The result of the average linear coefficient of thermal expansion for the test concrete cubes is presented in Table 10, and Fig. 8. The average coefficient of thermal expansion for the $0 \%$ OPC replacement cement concrete is $11.07 \times 10-6 / \mathrm{oC}$ while that for the $10 \% \mathrm{SDA} / \mathrm{OPC}$ blended cement concrete is $10.42 \times 10-6 / \mathrm{oC}$. The linear coefficient of thermal expansion for the SDA/OPC blended cement concrete is significantly lower than that for the concrete made with $100 \%$ cement.

\subsection{Linear Shrinkage}

The result of linear shrinkage of the test cubes is presented in Table 11 and Fig. 9 as a percentage reduction in the size of the test specimens. The rate of shrinkage is more in the $0 \%$ OPC replacement concrete than in the $10 \%$ SDA/OPC concrete. Linear shrinkage is lower in the $10 \% \mathrm{SDA} / \mathrm{OPC}$ concrete than it is in the $0 \%$ concrete. There is an increase in linear shrinkage for both cement replacement in concrete with temperature. The shrinkage of both of the test specimens is typically categorized as plastic. The addition of $10 \%$ SDA in the blended cement contributed to decreased shrinkage of concrete produced with it. The highest shrinkage for both concrete occurred at the highest temperature; therefore, linear shrinkage is dependent on the temperature at which the concrete is exposed to. The linear coefficient of thermal expansion result indicated the magnitude of thermal mismatch between the aggregate and the cement.

\subsection{Cracking and Spalling}

Physical observation of the test specimens are made after exposing them to different temperatures. From the observation, there was a colour change in both concrete when exposed to temperatures of $600 \mathrm{oC}$ and $800 \mathrm{oC}$. The OPC concrete was whitish-grey at $600 \mathrm{oC}$ and light-brown at $800 \mathrm{oC}$ while the SDA blended cement concrete was dark-grey at $600 \mathrm{oC}$ and deep-brown at $800 \mathrm{oC}$. At $600 \mathrm{oC}$ the $\mathrm{OPC}$ concrete started experiencing slight fire cracks and surface peel-off, while the blended cement concrete only started experiencing fire cracks and surface peel-off at $800 \mathrm{oC}$. There was no any detachment of particles or peel-off of the concrete surface for the SDA blended concrete when exposed to temperatures of $200 \mathrm{oC}, 400 \mathrm{oC}$ and $600 \mathrm{oC}$ while the $\mathrm{OPC}$ concrete started having surface peel-off and dislodgement at a temperature of $600 \mathrm{oC}$. The dislodgement or detachment of small pieces of the surfaces of the concrete was more in the OPC than in the SDA blended cement at $800 \mathrm{oC}$. However, the spalling was not explosive at $800 \mathrm{oC}$ but a dislodgement of a minor portion of the concrete edges. The dislodgement of the concrete edges in the OPC concrete as compared with SDA blended concrete is relative.

\section{Figures and Tables}

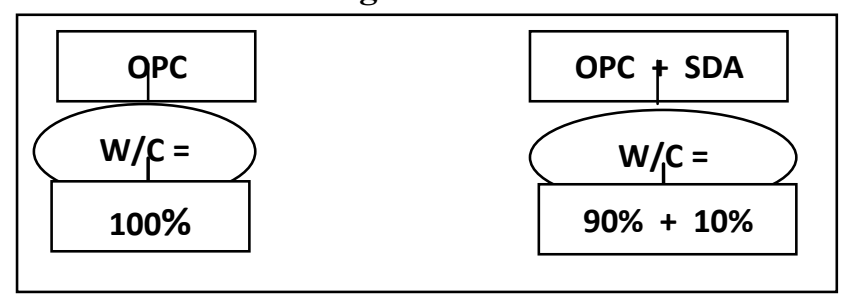

Figure 1 Experimental programme to study the effect of SDA pozzolana blended cement concrete at elevated temperature. 


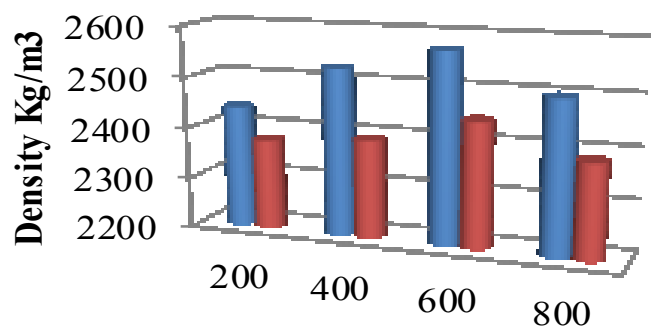

- Unheated Density

$\mathrm{Kg} / \mathrm{m} 3$

Temperature ${ }^{\circ} \mathrm{C}$

Figure 2 Densities of unheated and heated cubes at different temperatures for $0 \%$ OPC replacement

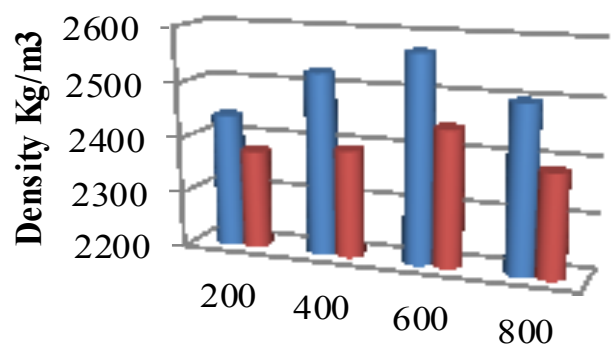

- Unheated Density

$\mathrm{Kg} / \mathrm{m} 3$

- Heated Density $\mathrm{Kg} / \mathrm{m} 3$

Temperature ${ }^{\circ} \mathrm{C}$

Figure 3Densities of unheated and heated cubes at different temperatures for $10 \%$ OPC replacement

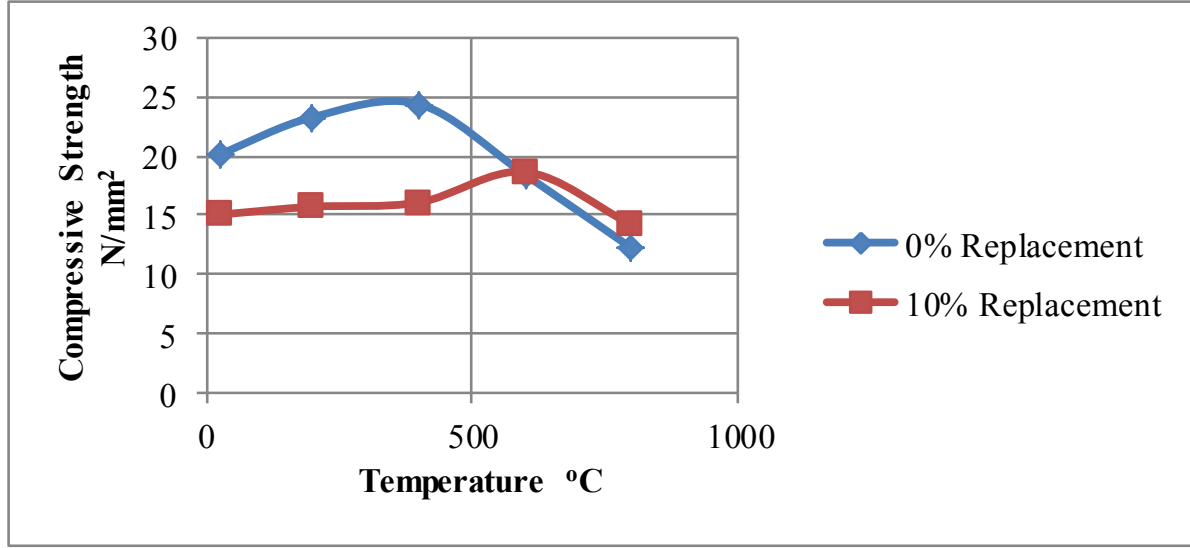

Figure 4 Compressive strength development at different temperatures

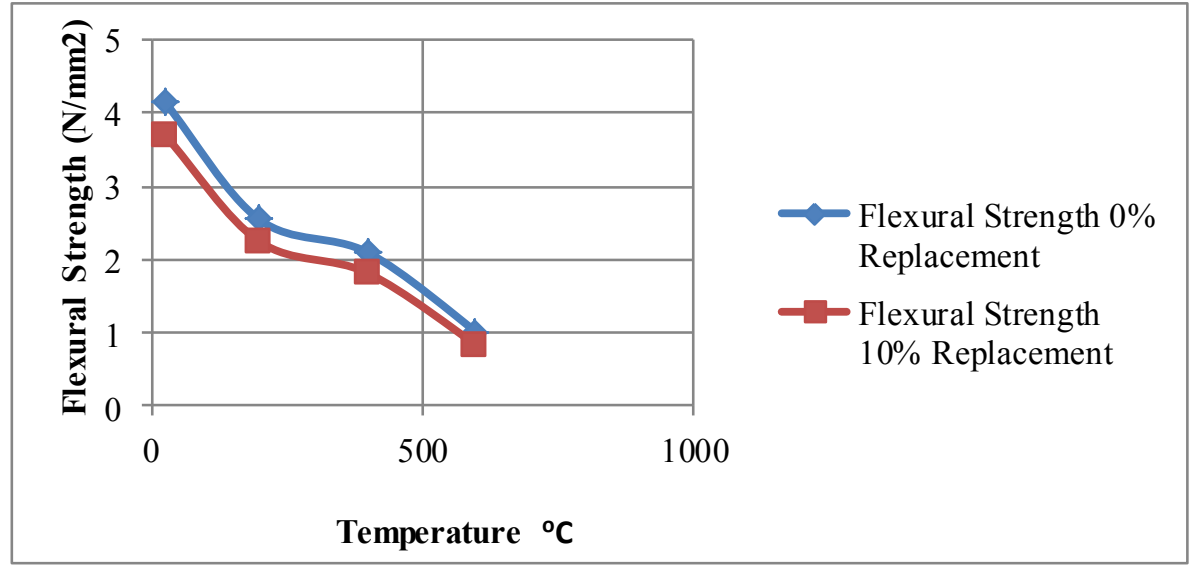

Figure 5 Flexural strength development at different temperatures 


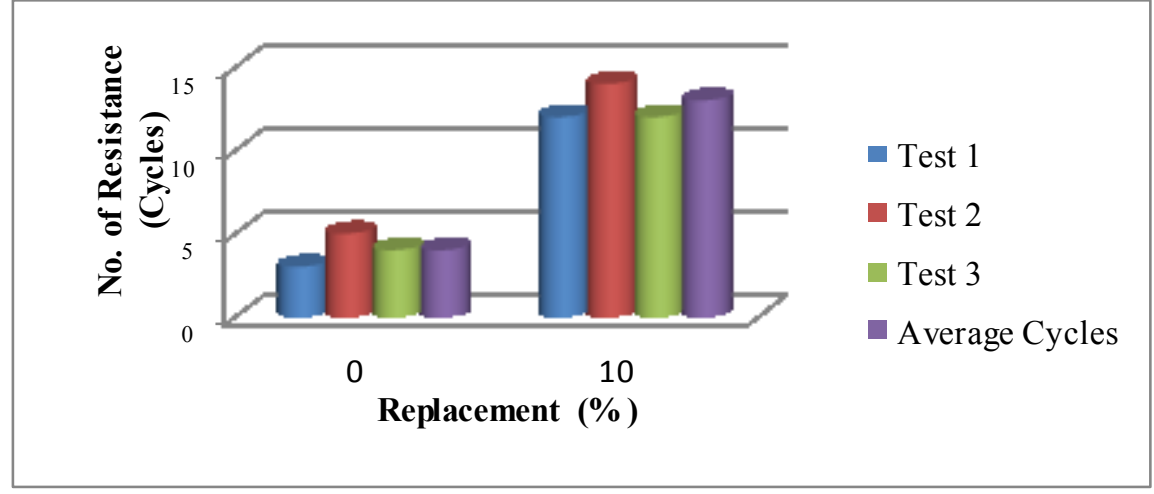

Figure 6 Thermal shock resistance

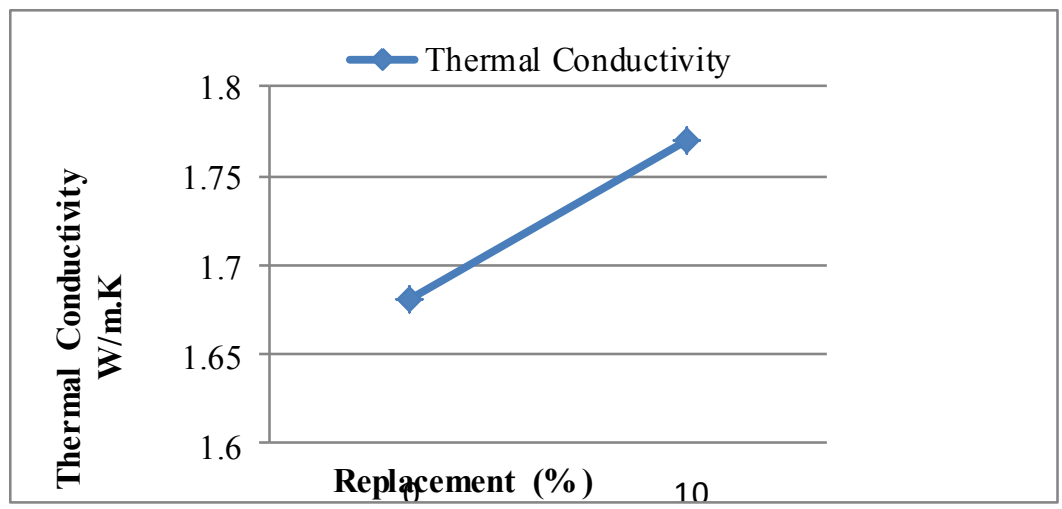

Figure 7 Variation of thermal conductivity with percentage replacement of cement content.

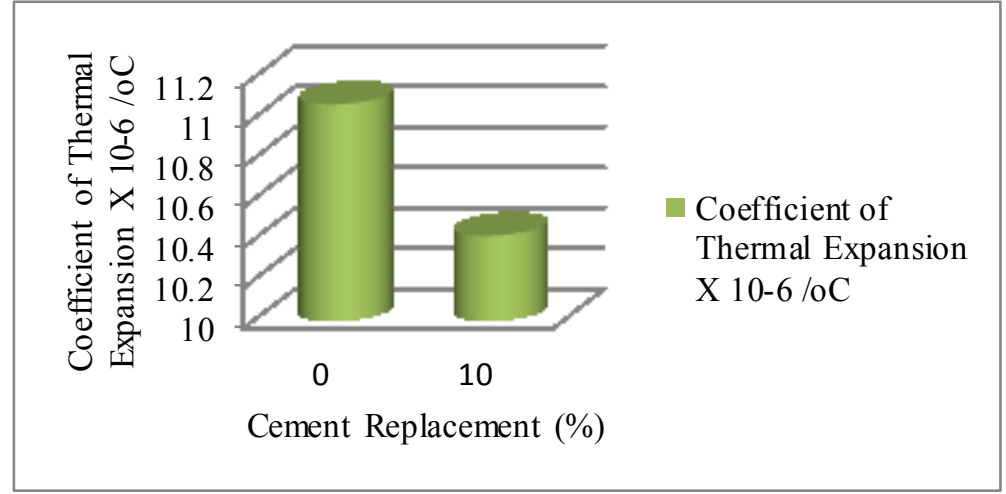

Figure 8Linear coefficient of thermal expansion

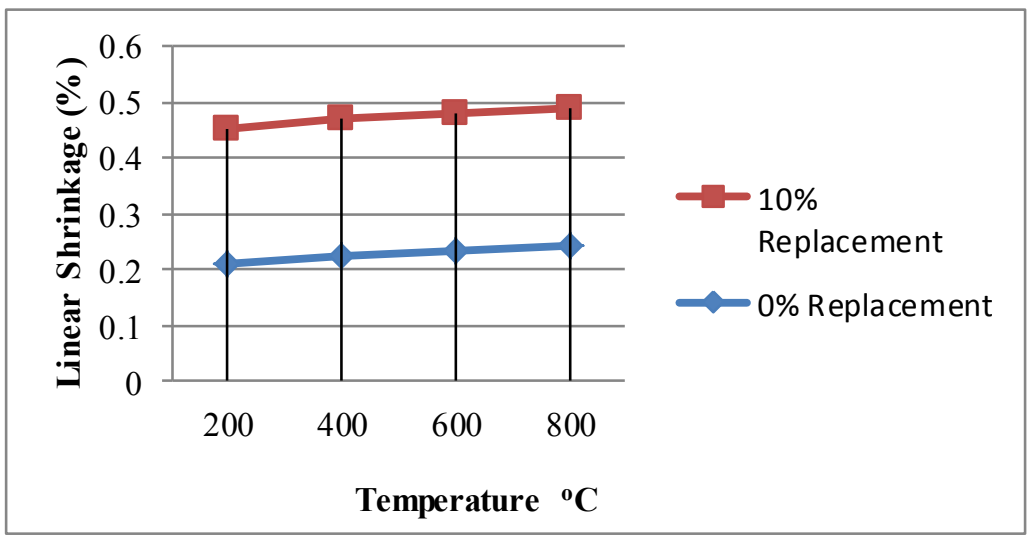

Figure 9Effect of saw dust ash (SDA) on linear shrinkage of concrete with temperature.

Table 1 Physical and Chemical Properties of Saw Dust Ash (SDA) 


\begin{tabular}{|l|c|}
\hline ELEMENTS & SAW DUST ASH [SDA] \\
\hline Moisture Content (MC) & $2.06 \%$ \\
\hline Specific Gravity & 2.03 \\
\hline Compacted Bulk Density & $4.97 \%$ \\
\hline Loss on Ignition & 10.05 \\
\hline $\mathrm{PHValue}^{\mathrm{N}}$ & $13.65 \%$ \\
\hline $\mathrm{Al}_{2} \mathrm{O}_{3}$ & $13.34 \%$ \\
\hline $\mathrm{Fe}_{2} \mathrm{O}_{3}$ & $48.95 \%$ \\
\hline $\mathrm{SiO}_{2}$ & $5.40 \%$ \\
\hline $\mathrm{CaO} \mathrm{O}$ & $4.60 \%$ \\
\hline $\mathrm{MgO}$ & $0.95 \%$ \\
\hline $\mathrm{MnO}$ & $9.01 \%$ \\
\hline $\mathrm{K}_{2} \mathrm{O}$ & $3.10 \%$ \\
\hline $\mathrm{P}_{2} \mathrm{O}_{5}$ & $1.00 \%$ \\
\hline $\mathrm{SO}_{3}$ & \\
\hline
\end{tabular}

Table 2 Mix Design per Cubic Metre of Concrete (1:2:4) Water/Cement Ratio 0.60

\begin{tabular}{ccc}
\hline PROPERTIES & CONTROL MIX & BLENDED MIX \\
\hline Cement- OPC $\left(\mathrm{Kg} / \mathrm{m}^{3}\right)$ & 25 & 22.5 \\
$\mathrm{SDA}\left(\mathrm{Kg} / \mathrm{m}^{3}\right)$ & 0 & 2.5 \\
Cementitous Binder $\left(\mathrm{Kg} / \mathrm{m}^{3}\right)$ & 25 & 25 \\
Coarse Aggregate $\left(\mathrm{Kg} / \mathrm{m}^{3}\right)$ & 50 & 50 \\
Fine Aggregate $\left(\mathrm{Kg} / \mathrm{m}^{3}\right)$ & 100 & 100 \\
Total Water $(\mathrm{Kg})$ & 15 & 15
\end{tabular}

Table 3 Density of Unheated and Heated Concrete Cubes

\begin{tabular}{|c|c|c|c|c|c|c|c|c|}
\hline & \multicolumn{3}{|c|}{$\mathbf{0 \%}$ OPC Replacement } & \multicolumn{3}{c|}{$\mathbf{1 0 \%}$ OPC Replacement } \\
\hline Temperature & $\mathbf{2 0 0 ^ { \circ } \mathbf { C }}$ & $\mathbf{4 0 0 ^ { \circ } \mathbf { C }}$ & $\mathbf{6 0 0}^{\circ} \mathbf{C}$ & $\mathbf{8 0 0}^{\circ} \mathbf{C}$ & $\mathbf{2 0 0}^{\circ} \mathbf{C}$ & $\mathbf{4 0 0}^{\circ} \mathbf{C}$ & $\mathbf{6 0 0}^{\circ} \mathbf{C}$ & $\mathbf{8 0 0}^{\circ} \mathbf{C}$ \\
\hline $\begin{array}{c}\text { Unheated Density } \\
\mathrm{Kg} / \mathrm{m}^{3}\end{array}$ & 2438.5 & 2526 & 2570.4 & 2497.8 & 2555.6 & 2555.6 & 2444.5 & 2503.74 \\
\hline $\begin{array}{c}\text { Heated Density Kg/m } \\
\text { Percentage Decrease }\end{array}$ & 2376.3 & 2392.6 & 2444.5 & 2385.2 & 2494.9 & 2469.7 & 2333.4 & 2314.83 \\
\hline $\begin{array}{c}\text { Pen Density Kg/m } \\
\text { in }\end{array}$ & 2.55 & 5.28 & 4.9 & 4.51 & 2.38 & 3.36 & 4.55 & 5.04 \\
\hline
\end{tabular}

Table 4 Variation of Compressive Strength with different Temperature Range

\begin{tabular}{|c|c|c|c|c|c|c|}
\hline \multirow{2}{*}{$\begin{array}{c}\text { Percentage } \\
\text { Replacement } \\
(\%)\end{array}$} & $\begin{array}{c}\text { Water/Cement } \\
\text { Ratio }\end{array}$ & \multicolumn{5}{|c|}{ Compressive Strength $\mathrm{N} / \mathrm{mm}^{2}$} \\
\cline { 3 - 7 } & $\begin{array}{c}\text { Room } \\
\text { Temperature }\end{array}$ & $\mathbf{2 0 0}^{\circ} \mathbf{C}$ & $\mathbf{4 0 0}^{\circ} \mathbf{C}$ & $\mathbf{6 0 0}^{\circ} \mathbf{C}$ & $\mathbf{8 0 0}^{\circ} \mathbf{C}$ \\
\hline 0 & 0.6 & 20.15 & 23.31 & 24.42 & 18.44 & 12.22 \\
\hline 10 & 0.6 & 15.06 & 15.73 & 16.09 & 18.67 & 14.20 \\
\hline
\end{tabular}

Table 5 Rate of Compressive Strength Gain and Loss

\begin{tabular}{|c|c|c|c|c|c|c|}
\hline \multirow{2}{*}{$\begin{array}{c}\text { Percentage } \\
\text { Replacement } \\
\text { (\%) }\end{array}$} & \multicolumn{4}{|c|}{ Strength Gain/Loss } & \multirow{2}{*}{$\begin{array}{c}\text { Average } \\
\text { Percentage } \\
\text { Gain (\%) }\end{array}$} & \multirow{2}{*}{$\begin{array}{c}\text { Average } \\
\text { Percentage } \\
\text { Loss (\%) }\end{array}$} \\
\hline & $\begin{array}{l}200^{\circ} \mathrm{C}: \text { Room } \\
\text { temperature }\end{array}$ & $400^{\circ} \mathrm{C}: 200^{\circ} \mathrm{C}$ & $600^{\circ} \mathrm{C}: 400^{\circ} \mathrm{C}$ & $800^{\circ} \mathrm{C}: 600^{\circ} \mathrm{C}$ & & \\
\hline 0 & 1.16 & 1.05 & 1.32 & 1.51 & 10.22 & 29.11 \\
\hline 10 & 1.04 & 1.02 & 1.16 & 1.31 & 7.59 & 23.94 \\
\hline
\end{tabular}


Table 6 Variation of Flexural Strength with different Temperature Range

\begin{tabular}{|c|c|c|c|c|c|c|}
\hline \multirow{2}{*}{$\begin{array}{c}\text { Percentage } \\
\text { Replacement } \\
(\%) \\
\end{array}$} & \multirow{2}{*}{$\begin{array}{c}\text { Water/Cement } \\
\text { Ratio }\end{array}$} & \multicolumn{5}{|c|}{ Flexural Strength $\left(\mathrm{N} / \mathrm{mm}^{2}\right)$} \\
\hline & & $\begin{array}{c}\text { Room } \\
\text { Temperature }\end{array}$ & $200^{\circ} \mathrm{C}$ & $400^{\circ} \mathrm{C}$ & $600^{\circ} \mathrm{C}$ & $800^{\circ} \mathrm{C}$ \\
\hline 0 & 0.6 & 4.16 & 2.55 & 2.1 & 1.02 & $\mathrm{Nil}$ \\
\hline 10 & 0.6 & 3.71 & 2.25 & 1.82 & 0.84 & Nil \\
\hline
\end{tabular}

Table 7 Rate of Flexural Strength Loss

\begin{tabular}{|c|c|c|c|c|c|}
\hline $\begin{array}{c}\text { Percentage } \\
\text { Replacement (\%) }\end{array}$ & $\begin{array}{l}200^{\circ} \mathrm{C}: \text { Room } \\
\text { temperature }\end{array}$ & $400^{\circ} \mathrm{C}: 200^{\circ} \mathrm{C}$ & $600^{\circ} \mathrm{C}: 400^{\circ} \mathrm{C}$ & $800^{\circ} \mathrm{C}: 600^{\circ} \mathrm{C}$ & $\begin{array}{c}\text { Average } \\
\text { Strength Loss }\end{array}$ \\
\hline 0 & 1.61 & 0.45 & 0.98 & & 1.01 \\
\hline 10 & 1.46 & 0.43 & 0.98 & & 0.96 \\
\hline
\end{tabular}

Table 8 Result of Thermal Shock Resistance Test at $800^{\circ} \mathrm{C}$

\begin{tabular}{|c|c|c|c|c|}
\hline \multirow{2}{*}{ Percentage Replacement (\%) } & \multicolumn{4}{|c|}{ Number of Resistance in Cycles } \\
\cline { 2 - 5 } & Test 1 & Test 2 & Test 3 & Average Cycle \\
\hline 0 & 3 & 5 & 4 & 4 \\
\hline 10 & 12 & 14 & 12 & 13 \\
\hline
\end{tabular}

Table 9 Results of the Thermal Conductivity Test

\begin{tabular}{|c|c|}
\hline Percentage Replacement $(\%)$ & Thermal Conductivity W/m.K \\
\hline 0 & 1.77 \\
10 & 1.68 \\
\hline
\end{tabular}

Table 10Results of the Linear Coefficient of Thermal Expansion Test

\begin{tabular}{|c|c|}
\hline Percentage Replacement $(\%)$ & Coefficient of Thermal Expansion X $10^{-6} \boldsymbol{~}^{\mathbf{0}} \mathbf{C}$ \\
\hline 0 & 11.07 \\
10 & 10.43 \\
\hline
\end{tabular}

Table 11Variation of Linear Shrinkage with different Temperature Range

\begin{tabular}{|c|c|c|c|c|c|}
\hline \multirow{2}{*}{$\begin{array}{c}\text { Percentage } \\
\text { Replacement }(\%) \\
\end{array}$} & \multirow{2}{*}{$\begin{array}{c}\text { Water/Cement } \\
\text { Ratio } \\
\end{array}$} & \multicolumn{4}{|c|}{ Linear Shrinkage (\%) } \\
\hline & & $200^{\circ} \mathrm{C}$ & $400^{\circ} \mathrm{C}$ & $600^{\circ} \mathrm{C}$ & $800^{\circ} \mathrm{C}$ \\
\hline 0 & 0.6 & 0.21 & 0.225 & 0.235 & 0.24 \\
\hline 10 & 0.6 & 0.24 & 0.244 & 0.246 & 0.25 \\
\hline
\end{tabular}

\section{Summaryand Conclusion}

Temperature influence on strength and durability of concrete is essential for it to have the characteristic of fire resistance. Concrete can be considered thermally stable when it retains its form and shape within the allowable limits, while exposed to high or elevated temperatures. This study finds out that particular chemical constituents of cement and pozzolanas are responsible for concrete performance under heat.

The conclusion from the above investigation can be summarized as follows:

1. The density of concrete is found to decrease with temperature increased. The average percentage loss in density for the control concrete is $4.31 \%$ while that for the SDA/OPC blended cement concrete is $3.83 \%$. The $\mathrm{SDA} / \mathrm{OPC}$ blended cement concrete therefore retained more of its density after been exposed to higher temperatures, than the control concrete made of $100 \%$ cement, as a result of the SDA having a lower specific gravity than the OPC. 
2. Concrete produced by blending cement with $10 \%$ SDA increased in compressive strength, when heated to $600 \mathrm{oC}$, while the compressive strength of concrete produced with OPC reduces at the same temperature.

3. Concrete produced by blending OPC with $10 \%$ SDA retained more of its compressive strength at the different temperatures exposed to, than the concrete produced using only OPC.

4. At an elevated temperature of $800 \mathrm{oC}$, both concrete specimens fail totally in flexure due to the effect of high heat on binding elements. The flexural strength of both the control concrete (at $0 \%$ OPC replacement) and SDA/OPC blended cement concrete (at 10\% OPC replacement) decreased as the temperature is increased. Their performance in flexure is relative to each other.

5. Replacement of OPC by $10 \%$ SDA increased the thermal shock resistance of the concrete by 11 cycles more than the concrete produced with $100 \%$.

6. The Saw dust ash (SDA) content had only a slight influence on thermal conductivity of the concrete as a result; cracking and spalling occurred more in the OPC concrete than in the SDA blended cement concrete.

7. Linear coefficient of thermal expansion for the SDA/OPC blended cement concrete is significantly lower than that for the concrete made with $100 \%$ cement. This is dependent on the temperature at which the concrete is treated.

8. The addition of in $10 \%$ SDA in the blended cement concrete contributed to the decreased in linear shrinkage of the concrete produced with the blended concrete. the shrinkage in OPC concrete is higher than in the $10 \% \mathrm{SDA} / \mathrm{OPC}$ concrete.

9. Slight fire cracks started occurring on the OPC concrete at $600 \mathrm{oC}$ with surface peel-off and dislodgement occurring at $800 \mathrm{oC}$. The blended cement concrete experienced slight fire cracks and surface dislodgement at $800 \mathrm{oC}$. Cracking and surface peel-off are relatively lower in the SDA blended cement concrete than in the OPC concrete.

From the tests results, it can be deduced that the replacement of OPC with about $10 \%$ SDA in concrete relatively improved performance of concrete at elevated temperature. Blending of OPC with $10 \%$ SDA can therefore be applied as a fire resisting bonding material in concrete. In order to have a research that is multi-facetted in its approach, it is recommended that further studies be conducted on the performance of concrete at elevated temperature by varying the percentage replacement of cement with SDA and also using different concrete grades.

\section{References}

[1] A.M. Neville, Properties of concrete: Special Issues in Materials Testing (Pearson Education, Fourth Edition 2007).

[2] G.A. Khoury, Performance of Heated Concrete-Mechanical Properties, Contract NUC/56/3604A with Nuclear Installations Inspectorate (Imperial College, London, August 1996).

[3] S.A. Sumaila, and O.F. Job, Properties of SDA-OPC Concrete: A Preliminary Assessment, Journal of Environmental Sciences, 3(2), 1999, 155-159

[4] I.I. Dashan, and E.E.I. Kamang, Some Characteristics of AHA/OPC Concretes: A Preliminary Assessment, Nigerian Journal of Construction Technology and Management, 2(1), 1999, 22-28.

[5] M.M. Morsy, S.S. Shebl, and A.M. Rashad, Effect of Fire on Microstructure and Mechanical Properties of Blended Cement Pastes Containing Metakaoline and Silica Fume. Asian Journal of Civil Engineering (Building and Housing), 9(2), 2008, 93-105.

[6] G. Narenda, Effect of Fire on Concrete, Concrete International Magazine, April, 2006, www.highbeam.com/doc/1P31106559491.html, Retrieved 22nd June, 2013

[7] M.S. Morsy, and S.S. Shebl, Effect of Silica Fume and MetakaolinePozzolana on the Performance of Blended Cement Pastes Against Fire. Ceramic Silikaty, 51(1), 2007, 40-44.

[8] CCAA, Concrete Basics: A Guide to Concrete Practice, A Publication of Cement Concrete and Aggregate Australia, 2004, 6th edition. www.concrete.net.au, retrieved 15th April 2010.

[9] B. Erlin, and W. Hime, The Fire Resistance of Concrete, Concrete Construction. Dec. 2004

[10] M. Zeiml, and R. Lackner, Experimental Investigation on Spalling Mechanisms in Heated Concrete, In Kukla, K. (2010), Concrete at high temperatures hygrothermo-mechanical degradation of concrete, doctoral thesis, Department of Civil Engineering, University of Glasgow, 2010. http://thesis.gla.ac.uk/1666/, retrieved 3rd July, 2011.

[11] Wanye, Heat Resistance Concrete, Everything about concrete.com, http://www.everything-about-concrete.com/heat-resistantconcrete.html

[12] D.J. Naus, The Effect of Elevated Temperature on Concrete Materials and Structures - A Literature Review (Prepared by Oak Ridge National Laboratory, Managed by UT-Battelle, LLC, P.O. Box 2008. Oak Ridge. U.S. Nuclear Regulatory Commission Washington, DC 20555-0001, 2006)

[13] P.K. Mehta, Advancements in Concrete Technology, Journal of Concrete International. 96(4), 1999, 69-76.

[14] H.K.M. Anwar, High Strength Blended Cement Concrete Incorporating Volcanic Ash: Performance at High Temperatures, Journal of Cement and Concrete Composites. 28, 2006, 535-545.

[15] D.S. Matawal, Application of Ashes as Pozzolana in Mortar and Concrete Production, 1 st National Academy Conference, 31 st 2nd September, 2005. 